\title{
Demonstration of renin mRNA, angiotensinogen mRNA, and angiotensin converting enzyme mRNA expression in the human eye: evidence for an intraocular renin-angiotensin system
}

Jürgen Wagner, A H Jan Danser, Frans H M Derkx, Paulus T V M de Jong, Martin Paul, John J Mullins, Maarten A D H Schalekamp, Detlev Ganten

\begin{abstract}
Aims/Background-All components necessary for the formation of angiotensin II, the biologically active product of the renin-angiotensin system (RAS), have been demonstrated in ocular tissue or vitreous and subretinal fluid. The tissue concentrations of renin were too high to be explained by admixture of blood. This raises the possibility of an intraocular RAS, independent of the RAS in the circulation.
\end{abstract}

Methods-In the present study, gene expression of RAS components in different parts of enucleated human eyes was investigated as evidence for tissue specific production.

Results-By using pooled tissue samples renin mRNA could be detected with the RNAse protection assay in retinal pigment epithelium (RPE) choroid, but not in neural retina or sclera. With reverse transcription polymerase chain reaction (RT-PCR), renin mRNA was detected in individual samples of RPE choroid and neural retina, and not anterior uveal tract or sclera. Angiotensinogen and angiotensin converting enzyme (ACE) gene expression could be demonstrated by RT-PCR in individual RPE choroid and neural retina samples and marginally in sclera samples.

Conclusion-These results support the concept of intraocular synthesis of angiotensin II, independent of renin, angiotensinogen, and ACE in the circulation. Since gene expression was highest in ocular parts, which are highly vascularised, local angiotensin II may be involved in blood supply and/or pathological vascular processes such as neovascularisation in diabetic retinopathy.

(Br f Ophthalmol 1996; 80: 159-163)

Correspondence to:

Dr A H J Danser

Department of

Pharmacology, room

EE1418b, Dr

Molewaterplein 50, Erasmus

University, 3015 GE

Rotterdam, the Netherlands.

Accepted for publication

10 August 1995
The renin-angiotensin system (RAS) plays an important role in the control of blood pressure and electrolyte homeostasis. The enzyme renin cleaves its substrate, angiotensinogen, to form angiotensin I. Angiotensin I is then converted by angiotensin converting enzyme (ACE) to angiotensin II, a potent vasoconstrictor and a stimulant of aldosterone release.

Components of the RAS are present both in the circulating blood and in tissues, including the eye. ${ }^{1-7}$ Their presence in the eye cannot be explained by admixture with blood, 127 suggesting that a local, intraocular, RAS may exist. Expression of RAS component genes in specific ocular tissues, however, has not been demonstrated so far. In a variety of other tissues - for example, adrenal, placenta, gonads, and brain, such expression has now been detected, ${ }^{8-10}$ thereby raising the possibility of local production of angiotensin II independent of the circulating RAS. ${ }^{11} 12$

The function of a local RAS in the eye is unknown. Angiotensin II receptors have been detected in retinal blood vessels, suggesting that angiotensin II may be involved in the regulation of retinal vascular tone. ${ }^{1314}$ Apart from a role in the control of ocular perfusion, angiotensin II may also affect the regulation of aqueous fluid haemodynamics, since local application of ACE inhibitors lowers intraocular pressure. ${ }^{15}$ The RAS has also been implicated in diseases of the eye. High levels of prorenin, the inactive precursor of renin, have been found in plasma of diabetic subjects and these high levels correlated with the presence of microvascular complications, proliferative retinopathy in particular. ${ }^{1617}$ Moreover, vitreous fluid obtained during eye surgery from diabetic patients with proliferative retinopathy contained higher levels of prorenin than vitreous obtained from non-diabetic subjects without retinopathy, ${ }^{1}$ suggesting that the intraocular RAS may be activated in diabetic subjects with proliferative retinopathy.

In view of its mitogenic and trophic actions, as well as its influence on angiogenesis, ${ }^{18} 19$ angiotensin II produced locally in the eye may play a role in the development of proliferative diabetic retinopathy. In order to demonstrate local generation of RAS components in the eye, we investigated gene expression of renin, angiotensinogen, and ACE in neural retina, retinal pigment epithelium (RPE) choroid, 
anterior uveal tract, and sclera obtained from enucleated human eyes both by RNAse protection assay and by reverse transcription polymerase chain reaction (RT-PCR).

\section{Materials and methods}

\section{OCULAR TISSUE COLLECTION}

Ocular tissues were removed from enucleated eyes and frozen in liquid nitrogen within 1-2 minutes after enucleation. The eyes were obtained from 18 subjects ( 12 men and six women; mean age 54 , range $26-78$ years). The indications for enucleation were: choroidal melanoma $(n=11)$, ciliary body melanoma $(n=1)$, phthisis bulbi $(n=2)$, neovascular glaucoma $(n=2)$, bullous keratopathy in a blind eye $(n=1)$ and an inflamed blind eye after trauma $(n=1)$. In the case of ocular melanoma only tissue remote from the tumour site was isolated.

Depending on what part of the eye had to be sent to the pathology department, neural retina, RPE choroid, anterior uveal tract, or sclera were isolated as follows. The isolation was performed at room temperature. Each eye was cut equatorially at the ora serrata, and the anterior segment was lifted off. The vitreous body was isolated by gently shaking it out of the eye cup. The neural retina was cautiously removed from the RPE with a thin glass rod and isolated by cutting it at the optic nerve. The choroid with adhering RPE layer ('RPEchoroid') was isolated by dissecting it from the sclera with a pair of fine scissors. Sometimes it was not possible to clearly separate neural retina and RPE choroid from each other. The anterior uveal tract, consisting of iris and ciliary body, was isolated by removing the lens from the anterior eye cup, then gently pulling the anterior uveal tract loose from the sclera and blotting it on dry paper to remove adhering vitreous. Cornea and lens were discarded. The ocular samples were frozen in liquid nitrogen immediately upon dissection and stored at $-70^{\circ} \mathrm{C}$ until analysis.

\section{RNASE PROTECTION ASSAY FOR RENIN}

${ }^{32} \mathrm{P}$ labelled RNA transcripts were prepared by transcription of a 291 nucleotide antisense RNA from a SacI/EcoRV fragment of the human renin $\mathrm{cDNA}$, subcloned into a $\mathrm{pGEM} 4$ vector, using T7 RNA polymerase. The transcript comprised 225 nucleotides of human renin antisense RNA and 66 nucleotides of vector encoded sequence. Total RNA was isolated from pooled human ocular tissues by lithium chloride precipitation. ${ }^{20}$ RNAse protection assays were performed according to Goedert et al. ${ }^{21}$ Samples of dried RNA were dissolved in $30 \mu \mathrm{l} 80 \%$ formamide, containing $40 \mathrm{mM}$ PIPES (pH 6.8), $400 \mathrm{mM} \mathrm{NaCl}, 1 \mathrm{mM}$ EDTA, and 200000 counts per minute (cpm) of the gel-purified transcript. After denaturation at $95^{\circ} \mathrm{C}$ for 60 seconds and incubation at $50^{\circ} \mathrm{C}$ for 20 hours, RNAse digestion was performed in $300 \mu \mathrm{l}$ buffer containing $40 \mu \mathrm{g} / \mathrm{ml}$ RNAse A (Sigma, St Louis, MO, USA) and $2 \mu \mathrm{g} / \mathrm{ml}$
RNAse $\mathrm{T} 1$ (Calbiochem, USA) at $37^{\circ} \mathrm{C}$ for 45 minutes. After digestion with proteinase $\mathrm{K}$, samples were electrophoresed on denaturing $5 \%$ polyacrylamide gels.

\section{POLYMERASE CHAIN REACTION (PCR)}

Total RNA was isolated from individual human ocular tissue samples by a modification of the lithium chloride method. ${ }^{20}$ After isolation, total RNA samples were checked by gel electrophoresis in a $1 \%$ agarose gel stained with ethidium bromide. Before polymerase chain reaction, total RNA was reversely transcribed to cDNA according to Kawasaki et al. ${ }^{22}$ One $\mu \mathrm{g}$ of total RNA was dissolved in $20 \mu \mathrm{l}$ of a reaction mixture containing $1 \mathrm{mM}$ of dATP, dCTP, dTTP, and dGTP, $1 \mu$ l of RNAsin (Boehringer Mannheim $\mathrm{GmbH}$, Mannheim, Germany), $50 \mathrm{mM} \mathrm{KCl}, 20 \mathrm{mM}$ Tris- $\mathrm{HCl}$ (pH 8.4), $2.5 \mathrm{mM} \mathrm{MgCl}, 10 \mu \mathrm{g} / \mu \mathrm{l}$ nucleasefree bovine serum albumin, and $200 \mathrm{U}$ of murine leukaemia virus reverse transcriptase (Gibco BRL, Eggenstein, Germany). After incubation for 45 minutes at $42^{\circ} \mathrm{C}$, the temperature was raised to $95^{\circ} \mathrm{C}$ and then quickly lowered on ice.

For amplification of the resulting cDNA, the volume was increased to $100 \mu \mathrm{l}$ with a solution containing $50 \mathrm{mM} \mathrm{KCl}, 20 \mathrm{mM}$ Tris- $\mathrm{HCl}$ (pH 8.4), and $2.5 \mathrm{mM} \mathrm{MgCl}_{2}$ and $25 \mathrm{pmol}$ of upstream and downstream primers as well as $3 \mathrm{U}$ of Taq polymerase (Perkin-Elmer/Cetus, Norwalk, CT, USA). The thermal profile used on a Perkin-Elmer/Cetus thermal cycler consisted of denaturation at $95^{\circ} \mathrm{C}$ for 1 minute, annealing at $60^{\circ} \mathrm{C}$ for renin and at $55^{\circ} \mathrm{C}$ for angiotensinogen and $\mathrm{ACE}$, respectively, for 1 minute, and of an extension temperature of $72^{\circ} \mathrm{C}$ for 1 minute for 26 cycles. Human renincDNA was amplified by oligonucleotides with the following sequence AAATGAAGGGGGTGTCTGTGG as sense primer (bases 851-872) and AAGCCAATGCGGTTGTTACGC (bases 1206-1227) as antisense primer. ${ }^{23}$ The amplification product was 376 base pairs (bp) in length spanning the second and third exon of renin-cDNA. The sense primer for the detection of ACE-cDNA spanned oligonucleotide bases 492-512 (GCCTCCCCAACAAGACTGCCA), and the antisense primer spanned base $860-880$ (CCACATGTCTCCAGCCAGATG) of the human ACE-cDNA. Human angiotensinogen primers were situated over the fourth and fifth exon with the sense primer (bases 1209-1231) CTGCAAGGATCTTATGACCTGC and the antisense primer (bases 1404-1426) TACACAGCAAACAGGAATGGGC. ${ }^{10}$ Specificity of amplified sequences of the PCR products was tested by restriction enzyme or direct sequence analysis as described by Paul et al. ${ }^{10}$ Southern blotting was performed as described before. ${ }^{24}$ The amplified cDNA sequences were transferred from $1.3 \%$ agarose gels to nylon membrane (Pall, Dreieich, Germany) in a LKB vacuum blot chamber using $0.25 \mathrm{~N} \mathrm{HCl}$ for precipitation for 30 minutes and subsequent neutralisation on $0.5 \mathrm{~N} \mathrm{NaOH}$ and $1.5 \mathrm{M} \mathrm{NaCl}$. 
Blotting was terminated after 2 hours on $20 \times$ SSC $(1 \times$ SSC: $0.15 \mathrm{M} \mathrm{NaCl}, 0.015 \mathrm{M}$ sodium citrate). cDNA was crosslinked to the nylon membrane in an ultraviolet linker (No 1800, Stratagene Inc, La Jolla, CA, USA). Membranes were prehybridised with $50 \%$ deionised formamide, $5 \times$ Denhardt's solution, $25 \mu \mathrm{g} / \mathrm{ml}$ herring sperm DNA for 4 hours. Hybridisation was done on the same buffer overnight at $60^{\circ} \mathrm{C}$ adding the corresponding probes, which were randomly labelled using ${ }^{32} \mathrm{P}-\mathrm{dCTP}$.

Labelled probes were purified on a Nensorb column (DuPont, Wilmington, DE, USA). Renin-cDNA was hybridised to a $1.3 \mathrm{~kb}$ long BamHI/HindIII rat renin-cDNA fragment obtained from the complete rat renin-cDNA cloned into a pGEM4 vector. A plasmid vector (Bluescript KS, pB35-19) containing 3334 bp of human ACE-cDNA was cut with EcoRI and BglII to yield 1.7 and $1.6 \mathrm{~kb}$ of human ACEcDNA, which were isolated from the $3.0 \mathrm{~kb}$ as probes. A 844 bp StuI fragment of human angiotensinogen-cDNA allowed detection of angiotensinogen-cDNA. Nylon membranes were washed after hybridisation at room temperature in $0.2 \times \mathrm{SSC}$ and $0.1 \%$ sodium dodecyl sulphate for 30 minutes and three times at $56^{\circ} \mathrm{C}$ for 30 minutes. Blots were exposed for 18 hours at $-80^{\circ} \mathrm{C}$ to XAR $x$ ray films (Eastman Kodak Co, Rochester, NY, USA).

Results

The RNAse protection assay was used in

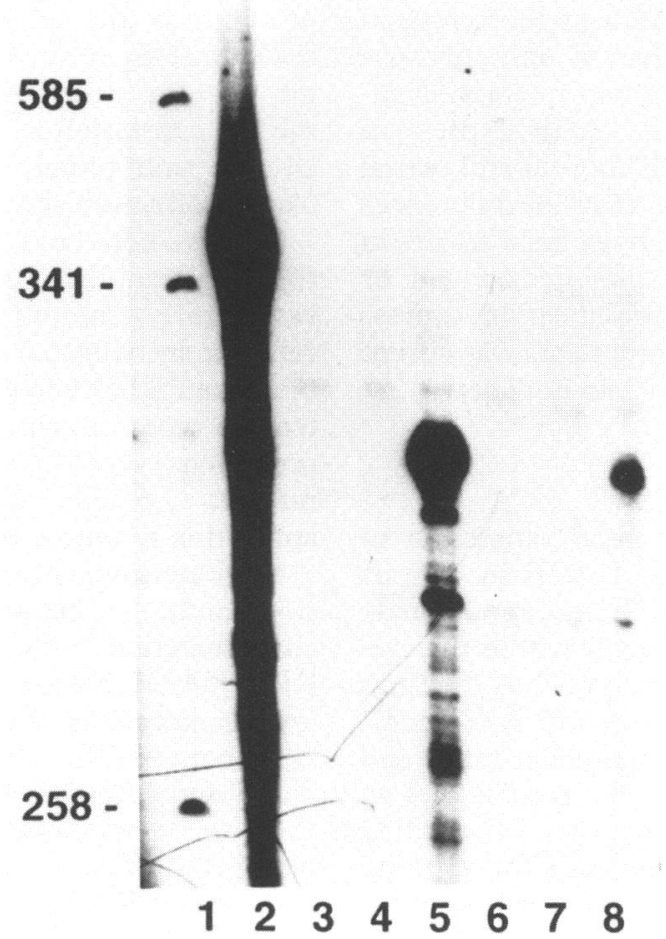

Figure 1 Ocular expression of renin $m R N A$. Renin $m R N A$ was determined in different layers of the human eye by $R N$ Ase protection assay using a human specific renin probe. For detection, ocular tissues from several patients were pooled. (1) pUC/Sau3a (length marker); (2) human renin probe; (3) $t R N A$; (4) rat kidney as specificity control; (5) human kidney (20 $\mu \mathrm{g})$; (6) sclera (35 $\mu \mathrm{g})$; (7) neural retina $(25 \mu \mathrm{g})$; (8) retinal pigment epithelium choroid/retina $(85 \mu g)$.

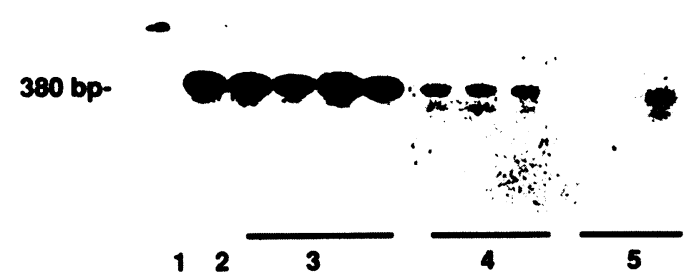

Figure 2 Demonstration of renin $m R N A$ expression in human eyes by the polymerase chain reaction. Southern blot of amplification products. (1) Negative control (without RNA); (2) human kidney; (3) retinal pigment epithelium choroid (four individual samples); (4) neural retina (three individual samples); (5) sclera (three individual samples).

pooled tissue samples, because it was not sensitive enough to detect renin-mRNA in individual eye samples. Examination of individual eye samples was possible only by using PCR Human kidney samples served as positive controls, since in these samples renin mRNA, angiotensinogen mRNA, and ACE mRNA are readily detectable. ${ }^{10}$

Using the RNAse protection assay, renin mRNA expression could be demonstrated in pooled RPE choroid samples, which also contained some neural retinal tissue, but not in neural retina alone or in sclera (Fig 1). Compared with the kidney, the ocular renin mRNA levels were low (Fig 1).

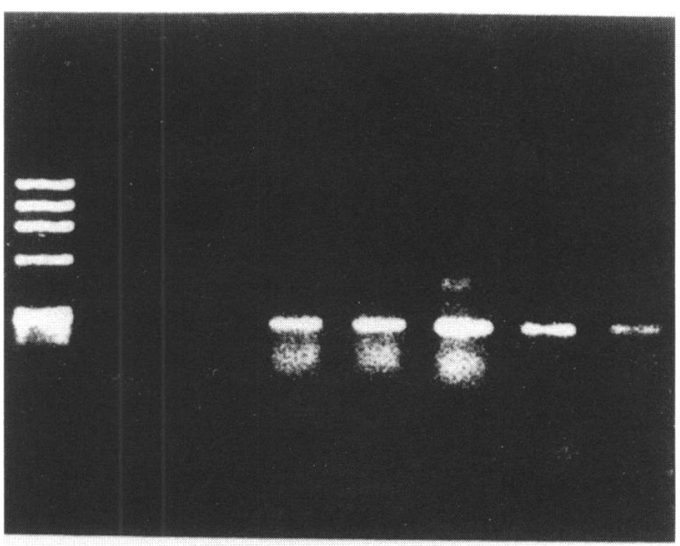

$\begin{array}{llllllll}1 & 2 & 3 & 4 & 5 & 6 & 7 & 8\end{array}$

Figure 3 Demonstration of angiotensinogen $m R N A$ in human eyes by the polymerase chain reaction. (Top) Agarose gel of amplification products. (1) PhiX174RF Hae Agarose gel of amplification products. (1) (3) humarker; (2) negative control; (3) human kidney; (4) neural retina; (5) retinal pigment epithelium (RPE) choroid; (6) neural retina; (7) RPE choroid; (8) RPE choroid. (Bottom) Southern blot of the amplification products. (1) Empty; (2) negative control; (3) human kidney; (4) neural retina; (5) RPE choroid; (6) neural retina; (7) RPE choroid; (8) RPE choroid. 


\section{5 bp - $\square-\infty$}

\section{$\begin{array}{llllll}1 & 2 & 3 & 4 & 5 & 6\end{array}$}

Figure 4 Demonstration of angiotensin converting enzyme $m R N A$ in human eyes by the polymerase chain reaction. Southern blot of amplification products. (1) Human kidney; (2) negative control; (3) neural retina; (4) retinal pigment epithelium (RPE) choroid; (5) RPE choroid; (6) neural retina.

The length of the PCR products of the different genes detected in the eye were identical to the corresponding amplification signal from the kidney (Figs 2-4). After reverse transcription of $1 \mu \mathrm{g}$ of total RNA and subsequent amplification, all three components of the RAS could be detected in both neural retina and RPE choroid.

Repeatedly, renin mRNA expression appeared to be higher in RPE choroid than in retina alone (Fig 2), confirming our findings with the RNAse protection assay, where renin mRNA was detected in RPE choroid but not neural retina. RPE choroid renin mRNA expression was similar in samples from eyes enucleated for choroidal melanoma and eyes enucleated for other reasons (data not shown). In scleral tissue, either no signal or a signal close to the detection limit for renin gene expression was observed, as was the case in the RNAse protection assay. No positive signal of renin mRNA expression was observed in the two anterior uveal tract samples we studied (data not shown).

Angiotensinogen and ACE gene expression were subjected to PCR analysis only, because of the small amount of human material available. Angiotensinogen and ACE expression were detected both in RPE choroid and neural retina (Figs 3 and 4). No marked differences were found between these two ocular tissues in the expression of either angiotensinogen or ACE. At the end of PCR amplification, expression of these two RAS components was absent or only marginal in sclera (data not shown).

\section{Discussion}

This study demonstrates gene expression of renin, angiotensinogen, and ACE in various parts of the human eye. These peptides may therefore be synthesised locally within the eye. These data, together with previous findings demonstrating the presence of RAS components in human and cattle ocular fluids and tissues, ${ }^{1-7}$ strongly support the existence of an intraocular RAS independent of the circulating RAS. Renin gene expression was found to be highest in the RPE choroidal layer, both by RNAse protection assay and by polymerase chain reaction. Using the polymerase chain reaction, renin mRNA could also be detected in the neural retina. The polymerase chain reaction only gives a rough measure of gene expression. However, in view of the results obtained with the RNAse protection assay, expression of the renin gene is most likely lower in the neural retina than in the RPE choroid. In support of this assumption, the ocular renin and angiotensin levels were found to be lower in the retina than in the RPE choroid. ${ }^{2}$

In human eyes, prorenin, the inactive precursor of renin, has been detected in aqueous, vitreous, and subretinal fluid, the highest levels being present in the latter. ${ }^{1}$ Based upon these findings and the present study, one may speculate about the source of prorenin in human ocular fluids. As we have shown previously, prorenin leakage from plasma is only a minor source of ocular fluid prorenin. ${ }^{1}$ Prorenin produced in the retina can directly enter the vitreous fluid, whereas prorenin synthesised in the choroid would first have to pass the RPE. This layer is part of the so called 'blood-retinal barrier', which is normally impermeable to proteins such as prorenin. Under pathophysiological conditions - for instance, in eyes affected by proliferative retinopathy in diabetic subjects, ${ }^{25}$ partial breakdown of the bloodretinal barrier may occur, so that this barrier becomes permeable to prorenin.

Two lines of evidence support prorenin production in the posterior part (retina and/or RPE choroid) of the eye. Firstly, as mentioned above, prorenin levels were higher in vitreous than in aqueous. ${ }^{1}$ Secondly, a prorenin gradient exists in vitreous fluid with the lowest levels present in the most anterior parts of the vitreous. $^{2}$ Others have suggested that ocular prorenin is produced in the anterior uveal tract, $^{3}$ since they detected prorenin by immunohistochemistry in the pars plicata of the ciliary body. We also detected renin and prorenin in the anterior uveal tract (ciliary body and iris) of the bovine eye. ${ }^{2}$ However, in the present study we failed to show renin mRNA expression in this part of the eye. RPE choroid and retina, therefore, are the most likely production sites of (pro)renin in the eye.

It has not been clarified yet, whether (pro)renin at these sites is expressed in the vasculature (smooth muscle or endothelial cells) or in neuronal and/or glial cells. In the brain, renin has been demonstrated in the latter two types of cells. ${ }^{26}$ Interestingly, a recent preliminary study localised renin in human and rat eyes to Müller cells of the retina, in close apposition to retinal blood vessels. ${ }^{27}$

Angiotensinogen and ACE mRNA expression could be demonstrated by polymerase chain reaction both in neural retina and in RPE choroid. No marked difference was found for the expression of either angiotensinogen or ACE between the two layers, in contrast with our observations on renin. Scleral expression was low or undetectable for all three components of the RAS.

Angiotensinogen is known to be present in brain glial and neuronal cells, ${ }^{28}$ but, as for renin, its gene expression in the highly vascularised RPE choroidal layer may also suggest a vascular origin of the peptide. Angiotensinogen mRNA has been demonstrated in vascular smooth muscle cells. ${ }^{29}$ Similarly, ACE is widely expressed in the brain; it is found in neuronal cells ${ }^{30}$ as well as in brain vascular 
endothelial cells. ${ }^{31}$ Ocular ACE expression may therefore occur in either vascular or neuroglial cells in retina and/or RPE choroid.

The co-expression of all components of the RAS in the retina and the RPE choroid is a prerequisite for intraocular angiotensin II production. Angiotensin II generated locally in retina and RPE choroid may be an important regulator of vascular blood flow. Indeed, angiotensin II has been reported to constrict retinal blood vessels. ${ }^{14}$ We have previously demonstrated that, relative to albumin, prorenin was twice as high in vitreous fluid obtained from eyes affected by proliferative diabetic retinopathy as in vitreous fluid obtained from eyes of non-diabetic subjects. ${ }^{1}$ An activated intraocular RAS may lead to enhanced intraocular levels of angiotensin II, which, in view of its effects on growth, ${ }^{18} 19$ may contribute to the development of proliferative retinopathy.

1 Danser AHJ, van den Dorpel MA, Deinum J, Derkx FHM, Franken AAM, Peperkamp E, et al. Renin, prorenin, and immunoreactive renin in vitreous fluid from eyes with and without diabetic retinopathy. F Clin Endocrinol Metab 1989; 68: 160-6.

2 Deinum J, Derkx FHM, Danser AHJ, Schalekamp MADH. Identification and quantification of renin and prorenin in the bovine eye. Endocrinology 1990; 126: 1673-82.

3 Sramek SJ, Wallow IHL, Day RP, Ehrlich EN. Ocular renin-angiotensin: immunohistochemical evidence for the presence of prorenin in eye tissue. Invest Ophthalmol Vis Sci 1988; 29: 1749-52.

4 Sramek SJ, Wallow IHL, Tewksbury DA, Brandt CR, Poulsen GL. An ocular renin-angiotensin system. Immunohistochemistry of angiotensinogen. Invest Ophthalmol Vis Sci 1992; 33: 1627-32.

5 Ferrari-Dileo G, Ryan JW, Rockwood EJ, Davis EB, Anderson DR. Angiotensin-converting enzyme in bovine, feline and human ocular tissues. Invest Ophthalmol Vis Sci feline and human ocul

6 Weinreb RN, Sandman R, Ryder MI, Friberg TR. Angiotensin converting enzyme activity in human aqueous humor. Arch Ophthalmol 1985; 103: 34-6.

7 Danser AHJ, Derkx FHM, Admiraal PJ, Deinum J, de Jong PTVM, Schalekamp MADH. Angiotensin levels in the eye. Invest Ophthalmol Vis Sci 1994; 35: 1008-18.

8 Kumar A, Rassoli A, Raizada MK. Angiotensinogen gene expression in neuronal and glial cells in primary cultures of rat brain. $₹$ Neurosci 1988; 19: 287-90.

9 Dzau VJ, Ingelfinger JR, Pratt RE. Regulation of tissue renin and angiotensin gene expressions. $\mathcal{f}$ Cardiovasc Pharmacol 1986; 8 (suppl 10): S11-6.

10 Paul M, Wagner J, Dzau VJ. Gene expression of the renin angiotensin systems in human tissues: quantitative analysis by the polymerase chain reaction. $f$ Clin Invest 1993; 91: 2058-64.

11 Campbell DJ. Circulating and tissue angiotensin systems. f Clin Invest 1987; 79: 1-6.
12 Paul M, Bachmann J, Ganten D. The tissue reninangiotensin systems in cardiovascular disease. Trends angiotensin systems in cardiove
Cardiovasc Med 1992; 2: 94-9.

13 Ferrari-Dileo G, Davis EB, Anderson DR. Angiotensin binding sites in bovine and human retinal blood vessels. Invest Ophthalmol Vis Sci 1987; 28: 1747-51.

14 Rockwood EJ, Fantes F, Davis EB, Anderson DR. The response of retinal vasculature to angiotensin. Invest Ophthalmol Vis Sci 1987; 28: 676-82.

15 Constad WH, Fiore P, Samson C, Cinotti AA. Use of an angiotensin converting enzyme inhibitor in ocular hypertension and primary open-angle glaucoma. $A m \mathcal{F}$ Ophthalmol 1982; 105: 674-7.

16 Franken AAM, Derkx FHM, Man in 't Veld AJ, Hop WCJ, van Rens GH, Peperkamp E, et al. High plasma prorenin van Rens GH, Peperkamp E, et al. High plasma prorenin cations. F Clin Endocrinol Metab 1990; 71: 1008-15.

17 Luetscher JA, Kraemer FB, Wilson DM, Schwartz HC, Bryer-Ash M. Increased plasma inactive renin in diabetes mellitus: a marker of microvascular complications. $N$ Engl f Med 1985; 312: 1412-7.

18 Ariza A, Fernandes LA, Inagami $T$, Kim JH, Manuelidis EE. Renin in glioblastoma multiforme and its role in neovascularization. Am f Clin Pathol 1988; 90: 437-41.

19 Fernandez LA, Twickler J, Mead A. Neovascularization produced by angiotensin II. $\mathcal{F}$ Lab Clin Med 1985; 105: produced

20 Auffray C, Rougeon F. Purification of mouse immunoglobulin heavy chain mRNAs from total myeloma tumor RNA. Eur f Biochem 1980; 107: 303-14

21 Goedert M, Spillantini MG, Potier MC, Ulrich J, Crowther RA. Cloning and sequencing of the CDNA encoding an isoform of microtubule-associated protein tau containing four tandem repeats: differential expression of tau protein mRNAs in human brain. EMBO $\mathcal{f} 1989$; 8: 393-9.

22 Kawasaki ES, Clark SS, Coyne MY, Smith SD, Champlin R, Witte ON, et al. Diagnosis of chronic myeloid and acute lymphocytic leukemias by detection of leukemia-specific mRNA sequences amplified in vitro. leukemia-specific mRNA sequences amplified

23 Wagner J, Paul M, Ganten D, Ritz E. Gene expression and quantification of components of the renin-angiotensin system from human renal biopsies by the polymerase chain reaction. F Am Soc Nephrol 1991; 2: 421 (abstract). 24 Hirsch AT, Talsness H, Schunkert H, Paul M, Dzau VJ. Tissue-specific activation of cardiac angiotensin converting enzyme in experimental heart failure. Circ Res 1991; 69: 475-82.

25 Cunha-Vaz J, Faria de Abreu JR, Campos AJ, Figo GM. Early breakdown of the blood-retinal barrier in diabetes. Br f Ophthalmol 1975; 59: 649-56.

26 Hermann K, Raizada MK, Sumners C, Philips MI. Presence of renin in primary neuronal and glial cells from rat brain. Brain Res 1987; 437: 205-13.

27 Berka JL, Stubbs AJ, Wang Z-M, Alcorn D, Campbell DJ, Skinner SL. Localisation of renin to Müller cells of the retina. F Hypertens 1994; 12 (suppl 3): S130 (abstract).

28 Kumar A, Rassoli A, Raizda MK. Angiotensinogen gene expression in neuronal and glial cells in primary cultures of rat brain. $\mathcal{F}$ Neurosci 1988; 19: 287-90.

29 Naftilan AJ, Zuo WM, Ingelfinger JR, Ryan TJ, Pratt RE, Dzau VJ. Localization and differential regulation of angiotensinogen mRNA expression in the vessel wall. angiotensinogen mRNA express

30 Paul M, Printz M, Harms E, Unger T, Lang RE, Ganten D. Localization of renin (EC 3.4.23) and converting enzyme (EC 3.4.15.1) in nerve endings of rat brain. Brain Res 1985; 334: 315-24.

31 Chai SY, Mendelsohn FAO, Paxinos G. Angiotensin converting enzyme in rat brain visualized by quantitative in vitro autoradiography. Neuroscience 1987; 20: 615-27. 